The Sexual State 



\section{The Sexual State}

Sexuality and Scottish Governance, 1950-80

Roger Davidson and Gayle Davis

EDINBURGH

University Press 


\section{For Colin Davidson and Jean Davis, who have always been there for us}

(C) Roger Davidson and Gayle Davis, 2012

Edinburgh University Press Ltd

22 George Square, Edinburgh EH8 9LF www.euppublishing.com

Typeset in Sabon by 3 btype, and printed and bound in Great Britain by CPI Group (UK) Ltd, Croydon CR0 4YY

A CIP record for this book is available from the British Library

ISBN 9780748645602 (hardback)

ISBN 9780748649433 (webready PDF)

ISBN 9780748649457 (epub)

ISBN 9780748649440 (Amazon ebook)

The right of Roger Davidson and Gayle Davis to be identified as authors of this work has been asserted in accordance with the Copyright, Designs and Patents Act 1988. 